\title{
An Analysis of Guest Occupancy and Profit of Private and Public Hotels in Cox's Bazar
}

\author{
Thufathun Nessa Chowdhury ${ }^{1}$, MD. Mohiuddin Chowdhury ${ }^{2}$
}

${ }^{1}$ School of Business, East Delta University, Chittagong, Bangladesh

${ }^{2}$ Department of Finance and Banking, University of Chittagong, Chittagong, Bangladesh

\begin{abstract}
Purpose: The aim of this research was to find out the differences in guest occupancies and profits of the private and public hotels between and within the years 2008 and 2014.

Methodology: The researchers followed explanatory research to differentiate the data with statistical tools. The researchers undertook the deductive approach to test the hypothesis comparing occupancy and profit of the hotels. The researchers used survey and interview method in this study. Public and private hotels were chosen as sample during the year 2008 and 2014 from Cox's Bazar main beach area. The samples were selected based on judgment sampling method. The researchers used mono method and a crosssectional research by considering the data of the years 2008 and 2014 only.

This research mainly based on field survey instead of depending on the artificial figures provided by the hotel officials. The information was confirmed by several respondents during the interview.

Findings: Significant differences found in the occupancies and profits of the public and private hotels during the year 2008 and 2014 individually. Also, between the years, 2008 and 2014, differences were observed in occupancy and profit of the private hotels. No difference diagnosed in the occupancy and profit of public hotels between 2008 and 2014. In the survey, the researchers' diagnosed that the hotels had a common tendency to avoid Tax payment to keep the profit uncut.

Practical implications: Further research can be done to compare the tax earnings of the government from public and private sector at different period. New researchers can use this research data in further research to calculate the tax payment based on revenue earnings and occupancy.
\end{abstract}

Keywords: Private Hotels; Public Hotels; Occupancy; Contribution Margin; Profit before Tax JEL codes: L40, M20

\section{INTRODUCTION}

In Bangladesh the major part of tourism industry is built with huge natural beauty. Besides the natural resources, she has a glorious historical background (Das and Chakraborty, 2012). Bangladesh is also blessed with a rich cultural heritage and these natural treasures are sufficient to develop a tourism based economy (Tuhin and Majumder, 2011). Siddiqi (2003) examined the expert's opinion about the enormous potentials of developing tourism and eco-tourism based industry in Bangladesh. It was an observed phenomenon that other foreign countries like Malaysia, Indonesia, Singapore, Bangkok, Thailand, Vietnam, Korea, and Cyprus etc. had been developed a well organized tourism industry with less natural beauty.

The total number of tourists spots of Bangladesh categorized as Beaches, Archaeological Sites, Religious Places, Historical Places, Hills \& Islands, Forest \& Jungle and Others (Bangladesh Parjatan Corporation, 2013). Bangladesh Parjatan Corporation (2004) encountered that the Sundarbans (world's largest mangrove forest); the Buddhist Temples located at Ramu; heavenly beauty of Chittagong Hill Tracks; all these dwelled in Bangladesh.
Bangladesh Parjatan Corporation (2014) came up with a number of historical places such as, Mausoleum of Father of the Nation, National Memorial, Central Shahid Minar, Martyred Intellectual Memorial, the Graveyard of National Poet (Kazi Nazrul Islam), Bahadurshah park (known as Victoria Park), Curzon Hall, Baldha Garden, the Suhrawardy Uddyan (known as the race course), Old High Court Building, Dighapatiya Palace etc., which were also treated as invaluable assets and attractive visiting places for the tourist. Bangladesh also possesses diversified and vivid tribal lifestyles at Cox's Bazar, Rangamati, Khagrachari, Bandarban, Sylhet, and Mymensingh (Bangladesh Parjatan Corporation, 2004). Hasan (2005) recommended the same about the beautiful hilly regions conceiving different native ethnic group living distinctive lifestyles that were different from the rest of the community of Bangladesh.

Last but not the least, the most popular place for the tourist was Cox's Bazar (Mamun, Hasan, and Hossain, 2013) having the world's longest $(120 \mathrm{~km}$.) unbroken sea beach sloping down to the Bay of Bengal and surrounded by a scenic hilly background of deep green forests. Besides Inani beach in Ukhia and St. Martin Island in Teknaf, 
located within Cox's Bazar area, were other attractive spots for the foreign and local tourists (Hossain, 2006). The charming beauty of a sunset was another eye-catching scene behind the sea waves which make the visitor fascinated.

In the introduction phase, after a brief discussion of different mentionable tourists' places, this paper tried to introduce Cox's Bazar as the tourist capital of Bangladesh. Then it focused on the overview of the Cox's Bazar tourism business by reviewing some literatures. In the subsequent part, the relevant hypotheses were developed after specifying the objectives of the study. Next, a detailed discussion of the relevant literatures ascertained the research gap of the undertaken research. Literature review succeeded by the methodology. Later the researchers analyzed the calculations and findings step by step, and the study was ended with necessary recommendations.

\section{The Study Area - Cox's Bazar Beach}

After going through an overall summery of the tourist's spots of Bangladesh, the researchers came up with a conclusion that the most attractive and visited tourist spot in Bangladesh was Cox's Bazar. It became internationally renowned to have the position among the top 77 natural sites and competed with 440 natural sites of 220 countries in the first round of world seven wonders contest during the year 2007 and 2008 ("Sundarbans voted out of 7 wonders race", 2011). The scenic beauty of Cox's Bazar was described as "a conglomeration of miles of golden sands, towering cliffs, surfing waves, rare conch shells, colourful pagodas, buddhist temples and tribes, delightful sea-food" with an "unbroken, sandy, shark-free beach sloping down to the blue waters of the Bay of Bengal against the picturesque background of a chain of hills covered with deep forests" (Bangladesh Parjatan Corporation, 2013). Beside the main beach area, (Bangladesh Parjatan Corporation, 2004, p. 29) Kuakata, Inani, Himchhari Beach; Ramu; Moheshkhali, Sonadia, Teknaf and St. Martin's Island have been considered as other remarkable attractive tourist places of Cox's Bazar. Hossain (2006) found that because of this appeal Cox's Bazar turned into a lucrative and one of the most attractive places in the world. And all of these made Cox's Bazar as the tourist capital of Bangladesh.

\section{RESEARCH Focus}

As Cox's Bazar became the tourist capital in Bangladesh among a lot of tourist spots that was the main reason for choosing Cox's Bazar as the study zone for this research. The majority tourism based business in Bangladesh is developed surrounding the sea beach area of Cox's Bazar town. Different type of tourists, categorized in local and foreign, was used to visit this sea beach to enjoy the holidays and vacation every year. To accommodate these tourists 220 hotels and guest houses were available in Cox's Bazar (Mamun, Hasan, and Hossain, 2013). Whereas Ahammed (2010) identified around 300 private and government hotels, motels, cottage, rest and guest houses and restaurants developed for the tourists. Whatever the number of the hotels, the remarkable fact is, these hotels were the main revenue generating source for the government from the tourism sector of Cox's Bazar. That is why the researchers choose Cox's Bazar main beach area for selecting sample hotels. This study has specifically focused on the guest occupancy and profit of the hotels businesses around the sea beach area of Cox's Bazar. All the months of the year 2008 and 2014 were taken into consideration to calculate the differences in guest occupancy and profit earnings of the private and public hotels.

\section{Objectives of the Study}

- To compare the differences in guest occupancy and profit between the government and private hotels during the year 2008.

- To compare the differences in guest occupancy and profit between the government and private hotels during the year 2014.

- To compare the differences in guest occupancy and profit in the public hotels between the years 2008 and 2014 .

- To compare the differences in guest occupancy and profit in the private hotels between the years 2008 and 2014.

\section{Null Hypothesis}

- No differences were observed in guest occupancy and profit between the government and private hotels during the year 2008.

- No differences were observed in guest occupancy and profit between the government and private hotels during the year 2014.

- No differences were found in guest occupancy and profit in the public hotels between the years 2008 and 2014.

- No differences were found in guest occupancy and profit in the private hotels between the years 2008 and 2014.

\section{LITERATURE REVIEW}

This research covered many related facts in Cox's Bazar hotel and motel businesses such as differences in guest occupancy and profit per bed between and within the government and private hotels during the years 2008 and 2014. Not a single study found which can at least provide a partial picture of private and public hotel comparison to contribute to the present research results.

The study area of this research was Cox's Bazar at Bangladesh whereas Borooah (1999) done a study at Queensland in Australia focusing on the supply of hotel rooms. The study was based on the three Queensland regions (the Gold Coast, Whitsunday, and Cairns) and the result was generalized with a conclusion that the supply of guest rooms increases as the price of per occupied room increases but supply responses were not influenced by increasing room occupancy rate or by interest rate changes. Another study analyzed the relationship between hotel 
room pricing, occupancy and guest satisfaction in USA (Mattila, and O'Neill, 2003) where present study findings were based on the differences of guest occupancy and profit at Cox's Bazar with occupancy fluctuation and seasonal affect. Here the authors investigated the relationship between occupancy percentage and guest satisfaction. But the study concluded that overall guest satisfaction is mainly influenced by price and other satisfaction related components such as cleanliness, maintenance, and staff attentiveness. A research studied dynamic overbooking limits for guaranteed and nonguaranteed hotel reservations (Ivanov, 2007) whereas this study discussed about the actual occupied rooms not the advance bookings. The researcher addressed here that room revenue can increased by overbooking and more rooms (than the total capacity of available rooms at the hotels) can be confirmed. There were some drawbacks of over bookings such as financial cost, missed revenues and negative word-of-mouth. To overcome these problems detailed information collected on no-shows, cancelations, and last minute amendments (Kimes and McGuire, 2001) and a cancelation charge nearer to the room rent is practiced to limit the over bookings to observe the inverse effect (Ivanov, 2006). But it was necessary to maintain separate overbooking records when the hotel accepts both guaranteed and non-guaranteed bookings (Ivanov, 2007). In short, here the researcher was concern about the revenues of guaranteed and non-guaranteed rooms booked. Švec, Picha, Gilliam, Navratil, \& Doležalova (2012) tested the impact of visitor's segments on the perception of the product quality in accommodation establishments but the present study segmented the hotels into public and private sectors. The authors identified four factors (environment of accommodation, hygiene, service in the catering part, quality of the meals) and measured the quality of services provided in accommodation by differentiating the evaluation and perception of these factors. The research findings concluded that the perception of the first three factors were different based on age, repeated visits and the purpose of travel. Based on gender and duration of stay, differences were observed in perception and evaluation of the fourth factor. So, this study was a qualitative analysis of observation rather than the quantitative analysis of occupancy and profit. Afroz (2008) pointed out that the rooms were selected based on some identified attributes such as safety \& security, comfort, nearby dining, laundry, cleanliness, drinking water, and pool etc. But the author did not differentiate these facilities among the public and private investors to identify the differences in occupancy and profit. Hasan and Chowdhury (1995) examined the status of Bangladeshi hotels and restaurants which has contributed to the development of tourism. A very limited number of hotels and restaurants officially enlisted in this country. Dhaka, Chittagong, and Cox's Bazar were the cities where majority luxury hotels developed with high room fairs and low occupancy rate. The authors realized that the accommodation and dining facilities organized for the domestic visitors within an affordable room tariffs. Barros and Alves (2004) examined the operational activities of Portuguese hotel chain by proposing a framework for the evaluation of the hotels. The analysis of breaking the total productivity into technical and technological efficiency change had done with the help of Malmquist productivity index. The undertaken study was neither considered the restaurant business nor the productivity.

Mamun, Hasan, and Hossain (2013) conducted a study based on image analysis. A number of factors found which worked as the image indicators of Cox's Bazar beach as a tourist's destination. A significant difference observed in the image perception of respondents' based on gender, age, marital status, occupation, and education. The findings revealed that the tourist's perception about the image of Cox's Bazar were good. From the result, six factors were found related to the overall image development of Cox's Bazar which are Natural Beauty and Restful Atmosphere, Hygiene and Sanitation, Security and Accommodation quality, Hospitality and Information, Emergency and Caring Facility, and Shopping facility. But among these factors "hygiene and sanitation factor" and "security and accommodation quality factor" were more influential factors compared to the other factors in forecasting the development of image of Cox's Bazar. This analysis of image was unrelated to the present study where the study area was same.

Rest of the reviewed literatures were based on overall tourism practice in Bangladesh such as; an evaluative study on tourism in Bangladesh (Das and Chakraborty, 2012) and status of tourism research in Bangladesh (Hossain, Chowdhury and Ahmed, 2012), an appraisal of tourism industry development in Bangladesh (Tuhin and Majumder, 2011) and tourism marketing in developing countries like Bangladesh (Islam, 2013). The impact of tourism in Cox's Bazar was investigated by Ahammed (2010). This study provided some necessary information about the study area but did not contribute to the analytical part of the research. Since 1990 enormous growth was observed in Cox's Bazar tourism. Millions of tourists visit Cox's Bazar during the peak season and make the hotels, motels and guest houses full. Sometime visitors need to spend their night inside the vehicle because of not having available seats in the hotels. Multifaceted benefits were enjoyed by the local community and other stakeholders like investors, hoteliers, and tour operators and so on. But the overall implication or impact of tourism on the area on economical, social, cultural and environmental sides was yet to be analyzed with the respective pros and cons. This study answered two important questions by identifying the positive and negative impact of tourism in Cox's Bazar and some addressed issues for improving the current situation of tourism in Cox's Bazar. On the other hand, the present study can be considered as a little part of this overall impact analysis where some sample hotels were compared. And a difference between public and private 
hotels in guest occupancy and profit was revealed. Das and Chakraborty (2012) pointed out the necessity of the development of accommodation facilities to accelerate the growth at the tourism industry. Using some simple statistical tools, the investigators identified that the contribution of the tourism sector to the total GDP was significant. Hossain, Chowdhury and Ahmed (2012) felt the necessity of further studies to identify the answers to the "why" questions about customer (tourist) behavior. Majority studies based on customer (tourists) satisfaction and dissatisfaction had done through exploratory and descriptive research. But the answer to the question "why"that is, the causes of customer (tourist) satisfaction or dissatisfaction, remain unnoticed. Tuhin \& Majumder (2011) took the effort to present the current status of tourism in Bangladesh. This research also discussed the constraints and recommended the corrective steps to improve the situation. The necessity of a 'tourism policy' from the government was felt to accelerate the development of this industry. It is high time to provide public and private level investment along with the regional cooperation for the betterment of tourism in Bangladesh. Islam (2013) tried to diagnose the development trends, tourism marketing effectiveness, tourism marketing issues and potential strategies to increase the competitiveness of Bangladesh tourism.

Throughout the review of the literatures the researchers had been searching many studies to identify a little clue related to the concentration of this undertaken study. No research had covered the objectives of the present research. Different partially related studies did not match with the topic and the subject matter of this study. These related studies only provided some supporting literatures which specified the gap of the undergone research. By reviewing the above studies, the researchers felt a research gap which was not yet covered by any other published paper.

\section{Methodology OF THE STUdY}

Following the research 'onion' suggested by Saunders, Lewis and Thornhill (2008), the researchers set the research design of the study.

\section{The Research 'Onion'}

Research purpose: As the aim of this study was to find out the differences in guest occupancy and profit, the researcher followed explanatory research to differentiate the data with statistical tools.

Research Approach: The researchers undertook the deductive approach for testing the hypothesis comparing occupany and profit of the private and public hotels between and within the years of 2008 and 2014.

Sample: The researchers' choosen four public hotels and four private hotels during the year 2008 from Cox's Bazar main beach area as samples. In the year 2014, four public hotels and seven private hotels were taken as samples from the same place. The samples were selected based on judgment sampling method.
Research Strategies: The researchers used survey and interview method in this study. The study had done through face to face personal interview and telephone interview from the hotel officials. It was an unstructured interview as suggested by Kumar (2011) and during the interview the authors maintained a sequence of the questions. Questions had not written on paper, but those questions were asked in an organized format and the chronology or asking order was maintained. Relevant data captured from more than one person of each hotel. Since the respective chosen interviewee didn't have the answers to all the questions and as such the interviewee had referred the researchers to someone else for better information.

Research choice: In this study the researchers used a single data collection process and corresponding analysis which was named as mono method of doing research.

Time horizon: This study was a cross-sectional study considering the data of the specific years 2008 and 2014.

\section{Data Collection}

Secondary data Sources: Necessary and relevant information had collected from different secondary sources such as articles, journals, internet sources, newspapers, magazine and other secondary sources. Brochures of individual hotels were one of the secondary sources of revenue data.

Primary data Sources: Primary data had collected from the front desk officials of government and private hotels. In public hotels, information was collected from the respective managers of the whole operations. Data collected from those who were available at that moment. From government hotels average three people were contacted and in case of private hotels average two people had chosen because a single person is unable to give total information through conversation. Basically front desk people were available but to some extent the manager were found in the front desk.

In the end, the researchers concluded the research from the results of the hypothesis. Necessary conclusions and recommendations had drawn after analyzing the results.

\section{Collected Data}

During 2008, four government hotels and four private hotels were taken as sample. The data were collected through an unstructured questionnaire, later summarized in a tabular form. Some data were gathered from the price list or brochure of the respective hotels. The rest of the information was found from the oral interview of the hotel officials. 
Asian Business Review, Volume 4, Number 3/2014 (Issue 9)

ISSN 2304-2613 (Print); ISSN 2305-8730 (Online)

\begin{tabular}{|l|r|r|r|}
\hline Public Hotels During 2008 \\
\hline Sample Number & Occupancy & $\begin{array}{c}\text { Total Variable } \\
\text { Cost Per } \\
\text { Month }\end{array}$ & $\begin{array}{c}\text { Per Bed } \\
\text { Daily } \\
\text { Revenue }\end{array}$ \\
\hline Sample 1 & 48 & 50,000 & 1117 \\
\hline Sample 2 & 72 & 78,000 & 413 \\
\hline Sample 3 & 94 & 105,000 & 246 \\
\hline Sample 4 & 170 & 122,000 & 244 \\
\hline Total & 384 & 355,000 & $\mathbf{2 , 0 2 0}$ \\
\hline Average & 96 & $\mathbf{8 8 , 7 5 0}$ & 505 \\
\hline
\end{tabular}

\section{Private Hotels During 2008}

\begin{tabular}{|l|r|r|r|}
\hline Sample Number & Occupancy & $\begin{array}{c}\text { Total Variable } \\
\text { Cost Per } \\
\text { Month }\end{array}$ & $\begin{array}{c}\text { Per Bed } \\
\text { Daily } \\
\text { Revenue }\end{array}$ \\
\hline Sample 1 & 30 & 40,000 & 650 \\
\hline Sample 2 & 78 & 100,000 & 479 \\
\hline Sample 3 & 110 & 150,000 & 429 \\
\hline Sample 4 & 55 & 75,000 & 573 \\
\hline Total & 273 & 365,000 & $\mathbf{2 , 1 3 1}$ \\
\hline Average & 68 & $\mathbf{9 1 , 2 5 0}$ & $\mathbf{5 3 3}$ \\
\hline
\end{tabular}

During 2014, the same public hotels were encountered as sample with update data. But some additional private hotels were taken into account to enlarge the total number of sample size in this year. The updated data shows some differences which helped the researcher to test the hypothesis between the years.

\begin{tabular}{|l|r|r|r|}
\hline Public Hotels During 2014 & \multicolumn{1}{|c|}{} \\
Sample Number & Occupancy & $\begin{array}{c}\text { Total Variable } \\
\text { Cost Per } \\
\text { Month }\end{array}$ & $\begin{array}{c}\text { Per Bed } \\
\text { Daily } \\
\text { Revenue }\end{array}$ \\
\hline Sample 1 & 48 & 180,000 & 1420 \\
\hline Sample 2 & 73 & 400,000 & 858 \\
\hline Sample 3 & 76 & 700,000 & 713 \\
\hline Sample 4 & 250 & $1,440,000$ & 640 \\
\hline Total & 447 & $2,720,000$ & $\mathbf{3 , 6 3 1}$ \\
\hline Average & 112 & 680,000 & 908 \\
\hline
\end{tabular}

\begin{tabular}{l|r|r|r|}
\hline Private Hotels During 2014 \\
\hline Sample Number & Occupancy & $\begin{array}{c}\text { Total Variable } \\
\text { Cost Per } \\
\text { Month }\end{array}$ & $\begin{array}{c}\text { Per Bed } \\
\text { Daily } \\
\text { Revenue }\end{array}$ \\
\hline Sample 1 & 150 & 300,000 & 1200 \\
\hline Sample 2 & 249 & $2,000,000$ & 1115 \\
\hline Sample 3 & 450 & $3,400,000$ & 5114 \\
\hline Sample 4 & 220 & $1,100,000$ & 2083 \\
\hline Sample 5 & 150 & 400,000 & 1177 \\
\hline Sample 6 & 300 & $2,800,000$ & 1563 \\
\hline Sample 7 & 300 & $2,600,000$ & 2840 \\
\hline Total & $\mathbf{1 , 8 1 9}$ & $\mathbf{1 2 , 6 0 0 , 0 0 0}$ & $\mathbf{1 5 , 0 9 2}$ \\
\hline Average & $\mathbf{2 6 0}$ & $\mathbf{1 , 8 0 0 , 0 0 0}$ & $\mathbf{2 , 1 5 6}$ \\
\hline
\end{tabular}

\section{Calculations}

No software had used for extracting the result from the data rather manual calculation was done with the help of Microsoft Office Excel 2007. Another strength of this research was that it was based on field survey instead of depending on the artificial figures represented by the hotel officials. The information was confirmed by several respondents during the interview. So, the average rooms, daily occupancies, monthly variable costs and per bed daily revenues were calculated from data collected directly from the field and simple arithmetic mean was used to calculate the average figures.

From the calculation, a general observation was revealed. That is, more occupancy observed in public hotels but less revenue was earned compared to the private hotels during the year 2008. Higher variable costs found in private hotels that affect the calculation of contribution margin and profit at the advanced stage of the study result. The number of surveyed public hotels was four but to increase the sample size the researchers' undertaken seven private hotels in the survey during 2014. Here the calculation of average rooms, daily occupancies, monthly variable costs and per bed daily revenues were also done by using the formula of an arithmetic mean.

A higher average daily occupancy, monthly variable cost and per bed daily revenue were observed in the private hotels compared to the public hotels in this year. And the summarized information can be displayed together as follows:

\begin{tabular}{|c|l|c|c|c|}
\multicolumn{2}{|c|}{$\begin{array}{c}\text { Hotels During the Survey } \\
\text { Year }\end{array}$} & $\begin{array}{c}\text { No. Of } \\
\text { Hotel } \\
\text { Surveyed }\end{array}$ & $\begin{array}{c}\text { Number } \\
\text { of total } \\
\text { bed }\end{array}$ & $\begin{array}{c}\text { Average } \\
\text { Bed }\end{array}$ \\
\hline \multirow{2}{*}{2008} & Public Hotels & 4 & 384 & 96 \\
\cline { 2 - 5 } & Private Hotels & 4 & 273 & 68 \\
\hline \multirow{2}{*}{2014} & Public Hotels & 4 & 447 & 112 \\
\cline { 2 - 5 } & Private Hotels & 7 & 1,819 & 260 \\
\hline \multicolumn{2}{|c|}{ Total } & & 2,923 & 536 \\
\hline
\end{tabular}

These average beds per hotels had used in calculating per day occupancy with the help of a seasonal effect. The basic calculations started from here.

\section{Seasonal Effect}

The researchers identified some common characteristics of tourist arrival in different period of a year through an extensive survey. 100 respondents were surveyed to find the seasonal fluctuations in the tourist's flow. The researchers had interviewed 5 respondents from each private and public hotel. That is, 40 respondents participated in the survey during 2008 and 55 respondents were interviewed from different public and private hotels during 2014. In total the number of interviewee became 95 and rest of the five respondents involved in the restaurant businesses of the respective hotels located in the sea beach area. These respondents were another information source helped the researchers to cross check some collected data. Based on the information collected from the field, the researchers found all the respondents were unanimous that the tourist flow fluctuates during off-peak, semi peak and peak season of the year. Seasonal influence on the tourist flow had observed every year. The change in the climate from winter to summer starts from mid March.

April to August was felt as the hottest season in Bangladesh. During this time tourist flow fluctuates from $30 \%$ to $50 \%$. But September to November was the time when temperature falls. This time was considered as early winter. The flow of visitors increases gradually. The rate increased from $55 \%$ to $75 \%$ during this period. The winter 
time was considered as the super-peak period starts from December and continued till mid March. The tourist arrival rate increased to $85 \%$ and reach up to $95 \%$. But the frustrating fact was that a very little percentage of foreign visitors have been observed by the respondents throughout the year which was 5\% only. Overall rates of 95\% travelers come from local areas from different parts of the country in a year. A tabular form of tentative tourist arrival rate during the months of a year had summarized from the survey:

\begin{tabular}{|c|c|c|c|}
\hline $\begin{array}{c}\text { Seasonal } \\
\text { Change }\end{array}$ & Months & $\begin{array}{c}\% \text { of Tourist } \\
\text { Arrival }\end{array}$ & $\%$ of Discount \\
\hline \multirow{3}{*}{$\begin{array}{l}\text { Semi } \\
\text { Peak }\end{array}$} & September & $55 \%$ & \multirow{3}{*}{$50 \%$} \\
\hline & October & $65 \%$ & \\
\hline & November & $75 \%$ & \\
\hline \multirow{4}{*}{ Peak } & December & $90 \%$ & \multirow{4}{*}{$0 \%$} \\
\hline & January & $100 \%$ & \\
\hline & February & $90 \%$ & \\
\hline & March & $85 \%$ & \\
\hline \multirow{5}{*}{ Off-Peak } & April & $35 \%$ & \multirow{5}{*}{$70 \%$} \\
\hline & May & $30 \%$ & \\
\hline & June & $40 \%$ & \\
\hline & July & $45 \%$ & \\
\hline & August & $50 \%$ & \\
\hline
\end{tabular}

This seasonal effect was used in the calculations of per bed daily revenue, per bed costs and per bed daily occupancy of the months in a year.

Calculations of Occupancy and Profit with Seasonal Effect The calculations divided into three parts. In the first part, the researchers did the calculation based on full occupancy during the picking season. The conveniently occupied rooms with available number of beds per room made full occupancy of individual hotel. The occupancy had calculated by counting the total bed capacity of the hotels in a rush night. The revenues were calculated by multiplying the total number of rooms with respective rents as different room rents observed based on the room categories. Average per bed revenues were measured by adding all room rents and dividing this total by the total bed capacity of the hotels. Per bed variable cost had also measured in the same way that is total variable cost divided by total bed capacity of a particular hotel.

\section{The Detail Sheet:}

Second part was the detail sheet. The average daily occupancy during the peak season had calculated with seasonal effect. Then average monthly occupancies and per bed daily revenues were measured with seasonal effect. Per bed room-rents were also calculated by applying seasonal discount effect. The daily occupancy (with seasonal effect) and per bed room-rent (with seasonal effect) were multiplied by 30 to calculate the monthly revenues. The total yearly costs were divided by the per year occupancy to get per bed per day cost. It can easily be converted into monthly cost by multiplying the cost figures with 30 (Indicated by the * sign in the chart). The detail sheet and the summarized table of the detail sheet displayed the calculation of per day per bed monthly cost.
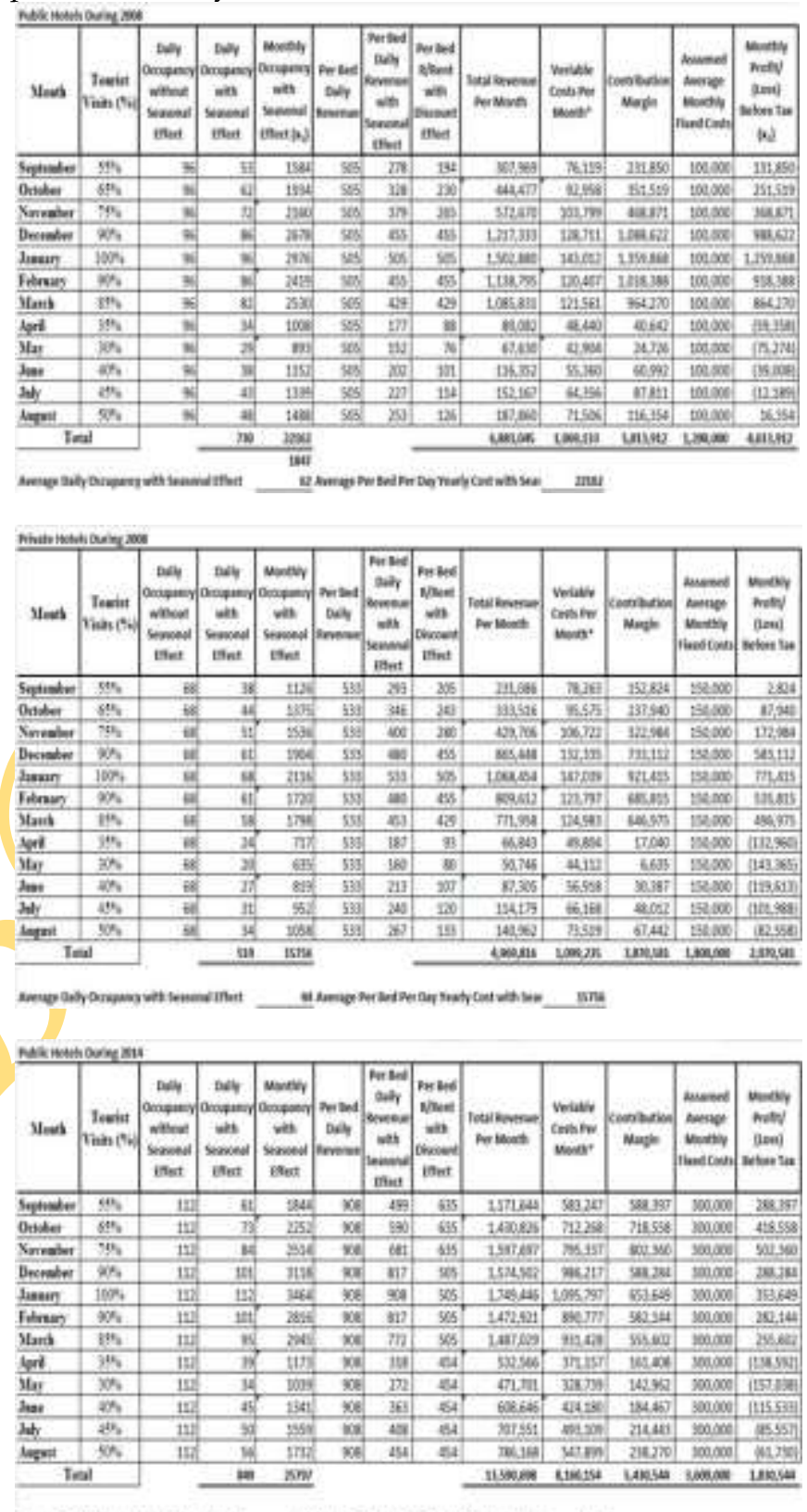

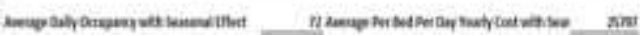

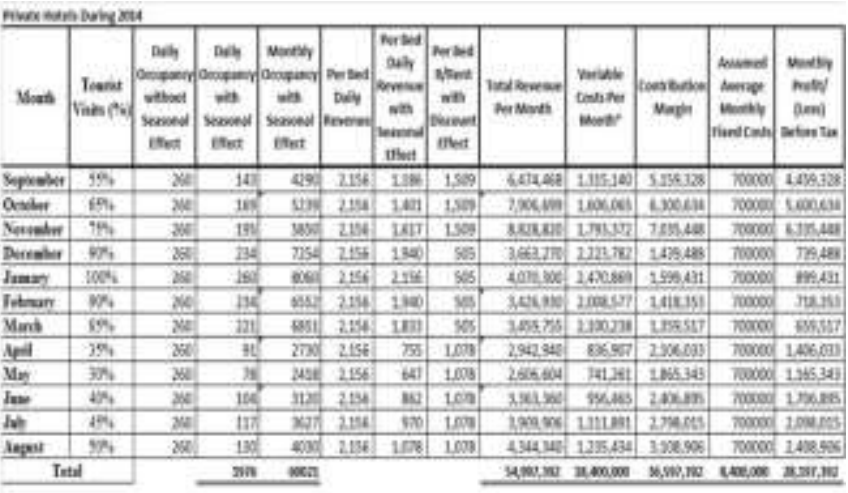

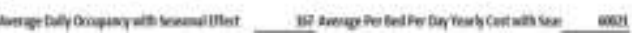


When revenues and costs had found, contribution margin and profit before Tax can easily be calculated by following the simple formula that is, Profit $=$ Revenue - (Fixed Cost + Variable Cost). From the revenues, the variable costs were deducted to get the contribution margin. The research findings could be ended here at contribution margin to visualize the formula of profit before Tax. So that further research could be taken into consideration to identify the exact fixed costs and accurate profit after Tax of the public and private hotels. The researcher calculated the profit before Tax by deducting the average fixed cost per month of the sample hotels.

As the monthly cost had collected in the survey, daily and yearly figures can easily be found. It was a known formula that, 30 days makes a month; 12 months and 365 days makes a year. Following this formula, the collected figures from the survey were converted into yearly or monthly or daily statistics. But in the detailed sheet the monthly occupancy, revenue, and variable cost were calculated by taking the exact days of the individual months from the year calendar.

\begin{tabular}{|c|c|c|c|c|c|c|c|}
\hline \multicolumn{8}{|c|}{ Summarized Average Data } \\
\hline \multicolumn{2}{|c|}{ Hotels During the Survey Year } & $\begin{array}{l}\text { Average } \\
\text { Daily } \\
\text { Occupancy }\end{array}$ & $\begin{array}{l}\text { Average } \\
\text { Yearly } \\
\text { eccupancy }\end{array}$ & $\begin{array}{l}\text { Average } \\
\text { Yearly }\end{array}$ & $\begin{array}{l}\text { Awerage } \\
\text { Mouthly }\end{array}$ & Average & Contribution \\
\hline \multirow{2}{*}{2008} & Public Hotels & 62 & $22 \pm 62$ & $6,883,043$ & 38,750 & $1,065,060$ & $\$, 813,912$ \\
\hline & Private Hotels & 44 & 15.756 & 4.969316 & 91.250 & $1.095,000$ & 3.870 .581 \\
\hline \multirow{2}{*}{2014} & Public Hotels & $\pi$ & 25,797 & $13,592,698$ & 630,050 & $8,160,080$ & $5,430,544$ \\
\hline & Private Hoteis & 167 & 50,021 & $54,997,392$ & 1800,000 & $21,600,000$ & $36,597,392$ \\
\hline
\end{tabular}

The third part contained the result of this research. The calculation of the table value and calculated value had done for testing the hypothesis. The formula for calculating t-value (Gupta and Gupta, 2008) of two independent samples was,

$$
t=\frac{\dot{x}_{1}-\dot{x}_{2}}{s} \times \sqrt{ } \frac{n_{1} n_{2}}{n_{1}+n_{2}}
$$

Where,

$$
s=\sqrt{\frac{\sum\left(x_{1}-\dot{x}_{1}\right)^{2}+\sum\left(x_{2}-\dot{x}_{2}\right)^{2}}{n_{1}+n_{2}-2}}
$$

The variables were decided according to the chronological items of the hypotheses. Such as in the year 2008 for occupancy and profit, $\mathrm{x} 1$ represented the public hotel and $\mathrm{x} 2$ represented the private hotel at hypothesis 2.2.1. Rest of the null hypotheses followed the same chronology in selecting variables for the occupancies and profits.

\begin{tabular}{|c|c|c|c|c|c|}
\hline & \multicolumn{2}{|c|}{ Occupancy } & \multicolumn{3}{|l|}{ Profit } \\
\hline & $(x-\dot{x})$ & $(x-\dot{x})^{2}$ & $x$ & $(x-\dot{x})$ & $(x-\dot{x})^{2}$ \\
\hline 1584 & -263 & 69169 & 131,850 & .252643 & 63828628850 \\
\hline 1934 & 87 & 7639 & 251,519 & .132974 & 17682158152 \\
\hline 2160 & 313 & 97969 & 368,871 & .15622 & 244056135 \\
\hline 2678 & 831 & 691226 & 988,622 & 604129 & 364971453354 \\
\hline 2976 & 1129 & 1274641 & $1,259,868$ & 875375 & 766280754219 \\
\hline 2419 & 572 & 327413 & 918,388 & 533895 & 285043888679 \\
\hline 2530 & 683 & 465943 & 864,270 & 479777 & 230186248979 \\
\hline 1008 & .839 & 703921 & $(59,358)$ & -443851 & 197003418600 \\
\hline 893 & .954 & 910498 & $(75,274)$ & .459767 & 211385794566 \\
\hline 1152 & -695 & 483025 & $(39,008)$ & -423501 & 179352779022 \\
\hline 1339 & -508 & 257861 & $(12,189)$ & -396682 & 157356580228 \\
\hline 1488 & -359 & 128881 & 16,354 & -368139 & 135526457141 \\
\hline 22162 & $\sum(x-\dot{x})^{2}$ & $5418185[x=$ & 4613912 & $\Sigma(x-\bar{x})^{2}$ & 2608862217923 \\
\hline 1847 & & \begin{tabular}{|l|l|}
$\dot{x}$ \\
\end{tabular} & 384493 & & \\
\hline
\end{tabular}

Guest occupancy \& profit in public hotels during 2008

\begin{tabular}{|c|c|c|c|c|c|c|}
\hline \multicolumn{4}{|c|}{ Occupancy } & \multicolumn{3}{|l|}{ Profit } \\
\hline & \begin{tabular}{l|l}
$x$ & 1 \\
$x$
\end{tabular} & $(x-\dot{x})$ & $(x-\dot{x})^{2}$ & $x$ & $(x-\dot{x})$ & $(x-\dot{x})^{2}$ \\
\hline & 1844 & -306 & 93713 & 288,397 & 135852 & 18455869886 \\
\hline & 2252 & 102 & 10356 & 418,558 & 266013 & 70762924599 \\
\hline & 2514 & 364 & 132769 & 502,360 & 349815 & 122370581325 \\
\hline & 3118 & 968 & 936685 & 288,284 & 135739 & 18425118975 \\
\hline & 3464 & 1314 & 1727253 & 353,649 & 201104 & 40442844670 \\
\hline & 2816 & 666 & 443689 & 282,144 & 129599 & 16795851009 \\
\hline & 2945 & 795 & 631409 & 255,602 & 103057 & 10620684371 \\
\hline & 1173 & -977 & 953796 & $(138,592)$ & -291137 & 84760480945 \\
\hline & 1039 & -1111 & 1233710 & $(157,038)$ & -309583 & 95841767066 \\
\hline & 1341 & .809 & 654481 & $(115,533)$ & .268078 & 71865911001 \\
\hline & 1559 & .591 & 349384 & $(85,557)$ & .238102 & 56692716045 \\
\hline & 1732 & -418 & 174620 & $(61,730)$ & -214275 & 45913929254 \\
\hline$x=$ & 25797 & $\sum(x-\dot{x})^{2}$ & $7341865[x$ & $1830544 \mid$ & $\sum(x-\dot{x})^{2}$ & 652948679144 \\
\hline$\dot{x}$ & 2150 & & $\dot{x}$ & 152545 & & \\
\hline
\end{tabular}

Guest occupancy \& profit in public hotels during 2014

\begin{tabular}{|c|c|c|c|}
\hline Occupancy & \multicolumn{3}{|l|}{ Profit } \\
\hline$(x-\bar{x})^{2}$ & $x$ & $(x-\bar{x})$ & $(x-\bar{x})^{2}$ \\
\hline 34922 & 2,824 & -169724 & \begin{tabular}{l|l}
28806305769 \\
\end{tabular} \\
\hline 3874 & 87,940 & .84608 & 7158449029 \\
\hline 49562 & 172,984 & 436 & \begin{tabular}{|l|l}
5 & 190464 \\
\end{tabular} \\
\hline 349488 & 583,112 & 410564 & 168563168315 \\
\hline 644408 & 771,415 & 598867 & 358641402044 \\
\hline 165568 & 535,815 & 363267 & 131962821303 \\
\hline 235601 & 496,975 & 324427 & 105252681726 \\
\hline 355663 & $(132,960)$ & -305508 & 93335339915 \\
\hline 460057 & $(143,365)$ & -315913 & 99801296388 \\
\hline 244036 & $(119,613)$ & -292161 & 85358001324 \\
\hline 130258 & $(101,988)$ & -274536 & 75370262312 \\
\hline 65089 & $(82,558)$ & -255106 & 65078892062 \\
\hline $2738524 \sum x=$ & \multicolumn{2}{|c|}{$2070581 \sum(x-\dot{x})^{2}$} & 1219328810652 \\
\hline \begin{tabular}{|l|l|}
$\dot{x}$ \\
\end{tabular} & 172548 & & \\
\hline
\end{tabular}

Guest occupancy \& profit in private Hotels during 2008 
Guest occupancy \& profit in private hotels during 2014

\begin{tabular}{|c|c|c|c|c|c|}
\hline \multicolumn{2}{|c|}{ Occupancy } & & \multicolumn{3}{|l|}{ Profit } \\
\hline$(x-\dot{x})$ & $(x-\dot{x})^{2}$ & & $x$ & $(x-\dot{x})$ & $(x-\dot{x})^{2}$ \\
\hline-712 & 506944 & & $4,459,328$ & 2109545 & 4450181368092 \\
\hline 237 & 56169 & & $5,600,634$ & 3250851 & 10568033888141 \\
\hline 848 & 719104 & & $6,335,448$ & 3985665 & 15885522943886 \\
\hline 2252 & 5071504 & & 739,488 & -1610295 & 2593048944885 \\
\hline 3058 & 9351364 & & 899,431 & -1450352 & 2103519558682 \\
\hline 1550 & 2402500 & & 718,353 & -1631430 & 2661563838540 \\
\hline 1849 & 3418801 & & 659,517 & -1690266 & 2856999995706 \\
\hline-2272 & 5161984 & & $1,406,033$ & .943750 & 890664218259 \\
\hline-2584 & 6677056 & & $1,165,343$ & -1184440 & 1402897068461 \\
\hline-1882 & 3541924 & & $1,706,895$ & -642888 & 413305285488 \\
\hline-1375 & 1890625 & & $2,098,015$ & .251768 & 63387044355 \\
\hline-972 & 944784 & & $2,408,906$ & 59123 & 3495497832 \\
\hline$\Sigma(x-\hat{x})^{2}$ & 39742759 & $\sum x=$ & 28197392 & $\sum(x-\hat{x})^{2}$ & 43892619652326 \\
\hline & & $\dot{x}$ & 2349783 & & \\
\hline
\end{tabular}

After applying the formula to the data, the following results were found to test the individual hypothesis.

\begin{tabular}{|c|c|c|c|c|c|}
\hline \multirow{2}{*}{$\begin{array}{c}\text { Hypothesis } \\
\text { Number }\end{array}$} & \multirow{2}{*}{\multicolumn{2}{|c|}{$\begin{array}{l}\text { Level of Significance }=5 \% \\
\text { Degrees of Freedom }=22\end{array}$}} & \multirow{2}{*}{ Calculated Value } & \multirow{2}{*}{ Table value } & \multirow{4}{*}{ Rejected } \\
\hline & & & & & \\
\hline \multirow{2}{*}{ 2.2.1. } & \multirow{2}{*}{ Public \&Private Hotels during 2008} & Occupancy & 2.1482 & \pm 1.717 & \\
\hline & & Profit & 14.9346 & \pm 1.717 & \\
\hline \multirow{2}{*}{ 2.2.2. } & \multirow{2}{*}{ Public \& Private Hotels during 2014} & Occupancy & -4.7753 & \pm 1.717 & \multirow{2}{*}{ Rejected } \\
\hline & & Profit & -3.7824 & \pm 1.717 & \\
\hline \multirow{2}{*}{ 2.2.3. } & \multirow{2}{*}{ Public Hotels between 2008 \& 2014} & Occupancy & -0.9745 & \pm 1.717 & \multirow{2}{*}{ Acceptec } \\
\hline & & Profit & 1.4755 & \pm 1.717 & \\
\hline \multirow{2}{*}{ 2.2.4. } & \multirow{2}{*}{ Private Hotels between 2008 \& 2014} & Occupancy & -6.5024 & \pm 1.717 & \multirow{2}{*}{ Rejected } \\
\hline & & Profit & -3.7059 & \pm 1.717 & \\
\hline
\end{tabular}

From the above table, the researchers came to the conclusion that significant differences observed between the occupancy and profit of the public and private hotels during 2008. Also, between the year 2008 and 2014, differences were found in occupancy and profit of the private hotels. During the year 2014, public and private hotels represented the significant difference in occupancy and profit. No difference diagnosed in the occupancy and profit of public hotels between 2008 and 2014. There were a number of reasons behind the acceptance of this hypothesis. These findings discussed in the conclusions and recommendations of this research paper.

\section{FINDINGS}

After analyzing the results, the researchers matched the interviewed information with tested data. From the interview, the researchers learned that 2012 was the most destructive year for the tourism business because of elections of Bangladesh Government. The political unrest and non-stop "Hartal" made the whole country stuck. Both the public and private hotels experienced almost no guest throughout the years. What the researchers' diagnosed in this research, the public hotels suffered a lot during this period. That is why, no significant differences observed in the public hotels between the year 2008 and 2014. Besides there were many other factors active to influence the occupancy and profit of the public hotels. No government subsidies were provided to the hotels and decreasing concern for the development of the hotels was one of the main reasons of downward growth of the public hotels. Akther (2001) also identified ineffective initiatives, absence of proper management plan and slow and insincere government effort for the tourism sector. There were insufficient investments in the tourism industry from the foreign and private sectors' (Tuhin \& Majumder, 2011). During the survey, the authority of the hotels also affirmed that the involvement of the government was quite vulnerable, and public sector contribution was very nominal. Five years back the condition of the public hotels was not that bad in the year 2008. At that time, the public hotels enjoyed higher occupancy, and profit compared to the private one. But after five years, the year 2014 displayed the reverse picture that was higher occupancy and profit in private hotels compared to the public one. And obviously due to higher investment in the private sector businesses of Cox's Bazar tourism private hotels conceived a substantial growth within this five years gap. These findings were also supported by another researcher. According to his view, necessary measures were taken by the Bangladesh Government to encourage the private sector. A positive role was played to promote domestic and international tourism in the country by facilitating tourist through development and diversifications (Islam, 2013). As a result, despite many difficulties arose because of the political unrest in the year 2012, the growth in occupancy and profit of the private hotels were not affected. Another important assumption of this research was, the tendency to avoid Tax payment became a common disease for all hotels. During 2008, among the four governments operated hotels, two of them were leased to a private management. This lease contract usually has done for 15 to 20 years for 32 to 50 Lacks Taka yearly. A flexible payment system had followed for repayment of the hotels. Money had paid on the installment basis. $25 \%$ had given in the first year. Remaining installment had paid at a flexible percentage; sometimes at $50 \%$, sometimes at $20 \%$ depending on yearly profit. Unfortunately, it was a difficult task for the government to collect money from the hotels. Often losses were shown to avoid repayment, and very often no tax was paid to the government. So based on these observations further research can be done to compare the tax earnings of the government from public and private sector at different period of the year.

\section{CONCLUSION AND LIMITATIONS}

The hotel officials, who were the respondent of this research, were reluctant to provide the information about cost and gross profit earnings. Because this information was considered as sensitive information for the owner's as revenue and cost calculate profit and Tax payment was based on net profit earnings of the hotels. Some of the respondents confessed that several years' management of the hotels tried to show loss instead of profit to avoid tax payment. 
Though the seasonal discount and seasonal variations taken into account for the calculation of occupancy, roomrent and variable cost, the researchers were bound to calculate contribution margin before calculating the fixed cost. The fixed costs of the hotels were assumed based on the opinion of the hotel officials during the interview.

Ahammed (2010) found about 300 private and government hotels, motels, cottage, guest houses and restaurants from Labonee to Kalatali beach areas developed for the tourist. In this study the researchers observed a substantial difference between the number of public and private hotels during 2008. The total government oriented hotels were only four and rest was all the private hotels. Surprisingly the number of public hotels was found the same in the years of 2008 and 2014. There were a lot of private hotels grown from 2008 to 2014 but no government investment had found to increase the number of public hotels in Cox's Bazar town during these years. This limitation of the research compelled the researchers to keep the sample size small. The researchers considered all category private hotels from five-star to two-star but the public hotels were almost twostar standards compared to the private hotels in the respective years. The respondents opined that no subsidies or financial co-operations made for the development of the public hotels during the study years. Government was not interested to approve any plan for decoration. No permission had given for the tourist guide. All these reason were active as the influential factors for poor development of the public hotels.

\section{SignificANCE OF the RESEARCH}

The significance of the undertaken research was inevitable. The calculation of this study represented increasing profitability of the sample hotels that indicated the overall profit possibilities of all the hotels located in Cox's Bazar sea beach area. Huge investment chances had discovered for the local and foreign investors in this research. Different investment fund from the investors could create more businesses that would generate government revenues from Tax. These investments would ensure development of the economy and the standards of living of Cox's Bazar town. New employment opportunities would be created in the new hotels. The public sector could use the private management to perform the operating activities based on yearly payment. In this way, a public private partnership can start a new era in the hotel businesses of Cox's Bazar. Hossain, Chowdhury and Ahmed (2012) recommended that the private and public investors of the country should formulate an effective national tourism policy to utilize this business opportunity and ensure sustainable growth of the industry with a focus on tourist satisfaction. Banladesh Bank should introduce investment policies for the public and private commercial banks to provide low interest loan to the new investors in Cox's Bazar. The respective government department could help the investors to acquire lands by formulating policies related to the site selections of the hotels. Government could make necessary changes in the Tax policies to declare "Tax Holiday" for the new investors.

\section{Recommendations}

The tourist capital of Bangladesh is Cox's Bazar. The economic value and social value of Cox's Bazar is inevitable in this country. Many researches had done focusing on tourism potentials, tourism facilities, and development plan for tourism, problem and prospects in tourism sector of the country (Mamun, Hasan, and Hossain, 2013). Das and Chakraborty (2012) demanded appropriate maintenance and logistic facilities with necessary concentrations to take care of these natural beauties to make the tourism sector an attractive one.

This research findings also supported the previous researchers when it was identified that public sector of Cox's Bazar tourism had been suffering from many difficulties. So it was strongly recommended that the government should concentrate on the development and further investment for the public hotels. More rooms and facilities should be provided to increase the occupancy and revenue earnings which could make sufficient profit for the government. A bundle of profit could ensure tax payment from both category (public and private) of the hotels. When public hotels would not become a Tax violator, the private sector would be encouraged to have a good practice of regular tax payment. Again, the government could declare Tax holiday for 10 to 20 years when the new investors would enjoy "No Tax" during this period. It would encourage investments in both (public and private) the sectors and would discourage the Tax defaulters.

Besides the accommodation facilities, the government should approve different plans necessary for decorations, saniations, restaurants, and other infrastructural facilities. Transportation services could be developed for quick and convenient access to Cox's Bazar town. Atleast three hours travel time of the visitors had taken to reach Cox's Bazar town through the existing road way. It could be made one hour distance from Chittagong city by avoiding too much turnings in the roads. Water way and railway transport became an emergent to enter the town through alternative ways.

Despite the accommodation and transport facilities, other facilities related to service had found in the hotels such as laundry service, room service, cleaning, newspapers and related services. To improve the overall service of the hotels the government should take care of each service related to the core accommodation service of the hotels. That would be helpful to ensure more occupancy, as well as more profit for the hotels. 


\section{REFERENCES}

Afroz, S. (2008). Lodge Selection and Satisfaction: A Case Study in Cox's Bazar, Bangladesh. Journal of Business Studies, 29(1), 207-220.

Ahammed, S. S., (2010). Impact of Tourism in Cox's Bazar, Bangladesh (Unpublished Master thesis). North South University, Bangladesh.

Akter, S. (2001). Tourism in Bangladesh: An Evaluation. Journal of Bangladesh Asiatic Society Bangladesh.

Bangladesh Parjatan Corporation. (2004). Bangladesh Tourism Vision 2020. (Ed.) Morshed, M. M. R. Planning, Training, \& Statistics Division, Dhaka.

Bangladesh Parjatan Corporation. (2013). Beach. May 12 from http:/ / www.parjatan.gov.bd/beaches.php

Bangladesh Parjatan Corporation. (2013). Coxs Bazar. Retrieved May 12 from http://www.parjatan.gov.bd/cox_bazar.php?category=76

Bangladesh Parjatan Corporation. (2013). Retrieved May 12 from http:/ / www.parjatan.gov.bd/

Bangladesh Parjatan Corporation. (2013). Tourists Attractions. Retrieved May 12 from http://www.parjatan.gov.bd/tourist_attract.php

Bangladesh Parjatan Corporation. (2014). Historical Places. Tourists Attractions. $\quad$ Retrieved $\quad$ May 8 from http://www.parjatan.gov.bd/index.php?option=com_tourism \&view=page\&layout=sub_menu\&sub_menu_id=3\&Itemid=

Bangladesh Parjatan Corporation. (2014). Retrieved May 21 from http://www.parjatan.gov.bd/

Bangladesh Parjatan Corporation. (2014). Retrieved May 21 from http://www.parjatan.gov.bd/index.php/en/component/t ourism/?view=page\&layout=sub_sub_menu\&sub_sub_me nu_id=195\&Itemid $=112$

Baroos, C. P., Alves, F. P., (2004). Productivity in the Tourism Industry. International Advances in Economic Research, 10(3), 215-225

Borooah, V. K., (1999). The Supply of Hotel Rooms Queensland, Australia. Annals of Tourism Research, 26(4), 985-1003

Das, R. K., Chakraborty, J., (2012). An Evaluative Study on Tourism In Bangladesh. Developing Country Studies, 2(1), 17-27

Gupta, S.P., Gupta, M.P., (2000), Business Statistics. Sultan Chad and Sons. New Delhi. India

Hasan, S. R., \& Chowdhury, A. I., (1995). Hotel and Restaurant Services and the Development of Tourism in Bangladesh. Dhaka University Journal of Business Studies, 16(2), 175-183

Hasan, S. R., (2005). Marketing Publicity and Sales Promotion For Tourism Development in Bangladesh. Paper Readout in the workshop on tourism Mater plan, Held on January, 15-16

Hossain, M. A. and Nazmin, S., (2006). Development of Tourism Industry in Bangladesh- An Empirical Study on its Problems and Prospects. Centre for Tourism and Hotel Management Research, Ga-1, Rashedul Hasan Bhaban, University of Dhaka, Dhaka.
Hossain, M. J., Chowdhury, F. S., Ahmed, R., (2012). Status of Tourism Research in Bangladesh: A Review of Literature. Bangladesh Research Foundation Journal. 1(1), 197-206

Islam, S M N., (2013). Tourism Marketing in Developing Countries: A Study of Bangladesh. Hospitality and Tourism Management, University of Strathclyde, Glasgow. (2014, June 24) Retrieved from http://www.scribd.com/doc/124513589/Tourism-

Marketing-in-Developing-Countries-a-Study-of-Bangladesh

Ivanov, S., (2006). Management of Overbookings in the Hotel Industry - Basic Concepts and Practical Challenges. Tourism Today. 6, 19-32

Ivanov, S., (2007). Dynamic Overbooking Limits for Guaranteed and Nonguaranteed Hotel Reservations. Tourism Today. 7, 100-108

Kimes, S.E., Mcuire, K.A. (2001). Function Space Revenue Management: Applying Yield Management to Function Space. CHR Working Paper, The Centre for Hospitality Research, School of Hotel Administration, Cornell University. (2005, December 16) Retrieved from http:/ / www.hotelschool.cornell.edu/chr/pdf/showpdf/ch $\mathrm{r} /$ research/working/functionspace.pdf

Kumar, R. (2011). Research Methodology; A step by step Guide for Beginnerrs. Dorling Kindersley Private Limited, New Delhi.

Mamun, M. A. A., Hasan, M. K., Hossain, S. A. K. M., (2013). Image of Cox's Bazar Beach as a Tourist Destination: An Investigation. International Review of Business Research, 9(5), 122 - 138

Mattila, A. S., O'Neill J. W. (2003). Relationships Between Hotel Room Pricing, Occupancy, and Guest Satisfaction: A Longitudinal Case of a Midscale Hotel in the United States. Journal of Hospitality \& Tourism Research, 20 (10), 1-15

Saunders, M., Lewis, P. and Thornhill, A., (2011). Research Methods for Business Students. New Delhi: Dorling Kindersley (India) Private Limited.

Siddiqi, R. (1997). Potential of Tourism in Bangladesh Remain Unrecognized, Unused. The Bangladesh Monitor, 7(4), 1-24

Stanislav, I., (2007). Dynamic Overbooking Limits for Guaranteed and Nonguaranteed Hotel Reservations. Tourism Today, 7, $100-108$

Sunderbans voted out of 7 wonders race (2011, November 12). The Daily Star. Retrieved from http:/ /archive.thedailystar.net/newDesign/newsdetails.php?nid $=209818$

Švec, R., Picha, K., Gilliam, V. L. W. B., Navratil, J., \& Doležalova, H., (2012). The Impact of Visitor Segments on the Perception of the Quality of the Product of Accommodation Establishments. Acta Universitatis Agriculturae Et Silviculturae Mendelianae Brunensis, LX 42(7), 399-408

Tuhin, M. K. W., Majumder, M. T. H., (2011). An Appraisal of Tourism Industry Development in Bangladesh. European Journal of Business and Management, 3(3), 287-297 